Justyna Figas-Skrzypulec

\title{
Kreacjonizm i Inteligentny Projekt poza granicami Stanów Zjednoczonych - zarys sytuacji
}

Z pewnością aktualnym centrum światowego kreacjonizmu są Stany Zjednoczone, jednak myliłby się ten, kto sądziłby, że kreacjonizm i ruch Inteligentnego Projektu nie przeniknął poza Amerykę, a nawet ten, komu nie przyszłoby do głowy szukać go poza Anglosaskim kręgiem językowo-kulturowym. Jak wynika z doniesień medialnych i badań opinii publicznej, kreacjoniści zadomowili się na wszystkich zamieszkanych kontynentach. Co więcej, ich idee przekraczają nie tylko granice geograficzne, lecz również wyznaniowe, znajdując oddźwięk wśród muzułmanów, katolików, prawosławnych oraz w Kościołach charyzmatycznych (pentekostalnych). W niniejszej pracy staram się podsumować niektóre usiłowania dziennikarzy i specjalistów oraz wyniki badań sondażowych, dotyczące globalnego wymiaru kreacjonizmu, zwracając szczególną uwagę na dociekanie przyczyn zjawiska i różnice kulturowe w jego recepcji.

Ronald Numbers, znany historyk nauki z Uniwersytetu Wisconsin-Madison, autor jednego z najbardziej wyczerpujących opracowań dotyczących kreacjonizmu ${ }^{1}$, umieścił przekonanie, iż kreacjonizm jest wyłącznie północnoamerykańskim zjawiskiem,

\footnotetext{
${ }^{1}$ Zob. R. Numbers, The Creationists: From Scientific Creationism to Intelligent Design, Harvard University Press, Cambridge (MA) 2006.
} 
na liście dwudziestu pięciu najpowszechniejszych mitów odnoszących się do religii i nauki. Numbers wskazuje na dwie organizacje jako szczególnie odpowiedzialne za obecność kreacjonistycznego misjonarstwa na świecie - Institute for Creation Research oraz Answers in Genesis ${ }^{2}$. Obie zajmowały się intensywnie przekładaniem podstawowych prac publikowanych przez kreacjonistycznych liderów na rozmaite języki ( $\mathrm{w}$ tym afrikaans i rosyjski, którymi posługuje się spory ułamek populacji światowej), jak również zakładaniem lokalnych filii, organizacją seminariów i odczytów oraz dystrybucją materiałów propagandowych (broszury, kasety VHS, DVD). Działalność ICR jest uważana za bezpośrednią przyczynę pojawienia się idei kreacjonistycznych na modłę amerykańską (czyli odbiegających od ewentualnych rodzimych intuicji kulturowych) w Turcji, Korei i Rosji, do czego nawiążę w dalszej części artykułu.

Przed prezentacją szczegółów dotyczących kilku krajów (przede wszystkim Turcji, Rosji, RPA, Wielkiej Brytanii i Szwajcarii), proponuję rzut oka na statystyki. W roku 2009 opublikowano wyniki badań Ipsos MORI dla British Council, przeprowadzonych na reprezentatywnych próbach ludności w dziesięciu krajach ${ }^{3}$ (Argentynie, Chinach, Egipcie, Hiszpanii, Indiach, Meksyku, Rosji, Republice Południowej Afryki, Stanach Zjednoczonych i Wielkiej Brytanii). $62 \%$ osób z Egiptu i $73 \%$ z RPA nigdy nie słyszało o Darwinie ani o teorii ewolucji, podobnie jak ponad połowa Rosjan i Chińczyków. Tylko około połowa Hiszpanów, Brytyjczyków, Rosjan i Amerykanów sądzi, że „możliwe jest jednocześnie wierzyć w Boga i utrzymywać pogląd, że życie na Ziemi, w tym gatunek ludzki, wyewoluował przez długi okres czasu na skutek doboru naturalnego" ${ }^{4}$. Spośród osób, które wiedziały cokolwiek

${ }^{2}$ Zob. R. Numbers (red.), Galileo Goes To Jail and Other Myths About Science and Religion, Harvard University Press, Cambridge (MA)-London 2009, s. 215-216.

${ }^{3}$ Darwin Survey Shows International Consensus on Acceptance of Evolution, 30.06.2009, <http://www.britishcouncil.org/darwin_now_survey_global.pdf $>, 12.02 .2012$.

${ }^{4}$ Tamże. 
o Darwinie i teorii ewolucji, 48\% Rosjan, 41\% Amerykanów i tylko $25 \%$ Egipcjan uważa, że istnieją wystarczające naukowe dane na rzecz tej teorii, natomiast w żadnym z badanych krajów odsetek ten nie przekroczył 77\% (np. Argentyna 57\%, Wielka Brytania $62 \%$, Meksyk 65\%). Inne badanie z 2011 roku - Ipsos MORI dla Reuters News - konfrontowało ponad 18000 respondentów z 23 krajów na wszystkich kontynentach z trzema poglądami ${ }^{5}$ :

- ewolucjoniści - wierzą, że ludzie powstali przez długi okres czasu ewoluowania, powstając jako w pełni ukształtowane ludzkie istoty, jakimi są dzisiaj, z niższych gatunków, takich jak małpy człekokształtne;

- kreacjoniści - wierzą, że istoty ludzkie zostały stworzone przez duchową siłę, np. Boga, którego wyznają, a także nie uznają, że ludziom dała początek ewolucja z innych gatunków, takich jak małpy człekokształtne;

- ci, którzy nie wiedzą, w co wierzyć i czasami się zgadzają, a czasami nie zgadzają z poglądami postulowanymi zarówno przez ewolucjonistów, jak i kreacjonistów.

Z pierwszym poglądem identyfikuje się $41 \%$ badanych, z drugim 28\%, a z trzecim 31\%. Najwięcej „kreacjonistycznych” odpowiedzi padło w Arabii Saudyjskiej, Turcji, Indonezji, RPA i Brazylii. „Niezdecydowanych” jest najwięcej w Rosji, Włoszech, Argentynie, Polsce, Hiszpanii i Francji, jednak nie wiadomo, co to dokładnie oznacza. Z pewnością część „niezdecydowanych” rzeczywiście odczuwa pewien chaos intelektualny albo nie czuje się na siłach, aby konsekwentnie wyrażać swoje zdanie z powodu niedostatków wykształcenia. Trzeba jednak zwrócić uwage na fakt, że to konkretne badanie jest nieco wadliwie skonstruowane, ponieważ nie daje możliwości sprecyzowania poglądów osobom

${ }^{5}$ Ipsos Global @dvisory: Supreme Beings, the Afterlife and Evolution, <http://www.ipsos-na.com/news-polls/pressrelease.aspx?id=5217>, 13.02.2012. 
skłaniającym się ku ewolucyjnemu teizmowi. We Włoszech, Polsce i Hiszpanii szczególnie można spodziewać się licznej grupy respondentów łączących wiarę w Boga z poglądami ewolucjonistycznymi, jako że Kościół Rzymskokatolicki, główne wyznanie w tych krajach, od wielu lat promuje takie wyważone stanowisko.

Nie wszyscy nauczyciele, w tym nauczyciele biologii, znajdują się po ewolucjonistycznej stronie barykady. Jak wynika z szeroko zakrojonych badań, których wyniki zaprezentowano na XIII Sympozjum International Organization for Science and Technology Education ${ }^{6}$, ze stwierdzeniem „Teoria ewolucji jest sprzeczna z moimi poglądami" zgadza się ponad $40 \%$ nauczycieli biologii w Burkina Faso i Rumunii, ponad 60\% w Libanie, ponad $70 \%$ w Senegalu, Tunezji i Maroku oraz $80 \%$ w Algierii. Wśród wszystkich respondentów, którzy odpowiedzieli na pytanie o wyznanie religijne (5249 nauczycieli języków, biologii oraz nauczania początkowego), z teorią ewolucji nie zgadza się mniej niż 10\% agnostyków, ponad $20 \%$ katolików i protestantów, $40 \%$ prawosławnych i ponad $70 \%$ muzułmanów.

Tym, co zwraca uwage osoby wychowanej w kręgu kultury zachodniej, jest fakt, że badania wyraźnie wskazują na drugie, obok amerykańsko-protestanckiego, silne centrum myśli kreacjonistycznej, jakim są kraje muzułmańskie. Media zwróciły szczególną uwagę na sytuację edukacyjną w Turcji, prawdopodobnie dlatego, że rozważa się jej wejście do Unii Europejskiej i że mamy tam do czynienia raczej z reislamizacja - po rewolucji Kemala Atatürka Turcja weszła na drogę świeckiego szkolnictwa, od której stopniowo się potem odwracała: „Między 1928 a 1948 książki o teorii kwantów, względności, ewolucji, literaturze zachodniej oraz nowoczesnej i klasycznej sztuce były tłumaczone przez rząd na turecki i dostarczane ludziom za darmo lub po bardzo niskich cenach.

\footnotetext{
${ }^{6}$ P. Clément, M.P. Quessada, C. Laurent, G. Carvalho, Science and Religion: Evolutionism and Creationism in Education. A survey of teachers conceptions in 14 countries, 2008, <http://repositorium.sdum.uminho.pt/bitstream/1822/8934/1/IOSTE_Evolution.pdf $>$, 13.02.2012.
} 
Kreacjonizm i przymusowe nauczanie religijne były nieobecne w tureckim systemie edukacyjnym w tym okresie" ${ }^{7}$. National Center for Science Education, którego misja jest obrona teorii ewolucji oraz nauk o klimacie, monitoruje i krytykuje działalność tureckich kreacjonistów. Taner Edis, zauważając, że główny nurt kreacjonizmu w Turcji wzoruje się ściśle na publikacjach i argumentacji lansowanej przez ICR, podkreśla: „(...) nie możemy wyjaśniać kreacjonizmu wyłącznie czynnikami ściśle denominacyjnymi [sectarian]. Kreacjonizm pobudza tradycyjne w religiach Abrahamowych przekonania dotyczące moralnego znaczenia naturalnego świata w opozycji do zagrożenia społeczną nowoczesnością" ${ }^{8}$. W latach 80. kreacjonizm pojawił się w szkołach, obok konserwatywnego wizerunku historii i obowiązkowych lekcji religii, w wyniku przemian politycznych - opresyjnych rządów Kenana Evrena i Turguta Özala. Państwo sponsorowało przekład sztandarowych dzieł wydanych przez ICR. W kolejnej dekadzie kreacjonistyczna propaganda trafiła też do masowego odbiorcy za sprawą działalności stowarzyszenia Bilim Araştirma Vakfi (Fundacja Badań Naukowych), finansowanego (poza datkami) częściowo z niejawnych źródeł, a częściowo z kieszeni radykalnych polityków, które rozsyłało bezpłatne książki, atlasy i broszury kreacjonistyczne. BAV niemal od początku swego istnienia utrzymywał kontakty z ICR. Duane Gish i Henry Morris, założyciele ICR, brali udział w kreacjonistycznej konferencji w Stambule w roku 1992. Morris poznał tureckich fundamentalistów już wcześniej, w czasie podróży, których celem było odkrycie pozostałości Arki Noego. Edis przypisuje sukces BAVu m. in. opłakanemu stanowi rynku czasopism i książek popularnonaukowych $\mathrm{w}$ Turcji ${ }^{9}$ oraz wylicza podobieństwa

\footnotetext{
${ }^{7} \ddot{U}$. Sayin, A. Kence, „Islamic Scientific Creationism”, Reports of the National Center for Science Education, 6, t. 19 (1999), <http://ncse.com/rncse/19/6/islamic-scientific-creationism>, 14.02.2012; tłum. własne.

${ }^{8}$ T. Edis, Cloning Creationism in Turkey, „Reports of the National Center for Science Education", 6, t. 19 (1999), <http://ncse.com/rncse/19/6/cloningcreationism-turkey>, 13.02.2012; tłum. własne.

${ }^{9}$ Zob. tamże.
} 
i różnice wobec wersji kreacjonizmu znanej z USA. Te pierwsze to przede wszystkim typowe argumenty, mianowicie nieobecność szczątków tzw. brakujących ogniw, niemożliwość funkcjonowania form pośrednich, niewiarygodność metod datowania, statystyczna niemożliwość ewolucji na poziomie molekularnym. Edis dodaje:

(...) podobnie jak wersja chrześcijańska, muzułmański fundamentalizm nie jest ruchem tradycjonalistycznym. Islamiści mają poparcie raczej w populacjach niedawno zurbanizowanych niż wśród chłopów (...). Są w tym podobni do amerykańskich kreacjonistów, którzy również konstytuują się pośród modernizujących się populacji, w tym wielu, którzy stali się częścią grup profesjonalnych, a starają się powielić własną kulturę w zmieniającym się środowisku społecznym ${ }^{10}$.

Interesujące wydają mi się także wskazane przez Edisa różnice:

- dużo ostrzejsze konsekwencje polityczne. Tu już nie chodzi o to, czy jest się poprawnym republikaninem/demokratą, ale o bycie wrogiem islamu, a takim grozi uwięzienie lub stanie się ofiarą przemocy, o czym świadczy chociażby próba zastraszenia sygnatariuszy antykreacjonistycznego oświadczenia z roku 1998, głównie członków Tureckiej Akademii Nauk;

- pominięcie potopu oraz dowodów na jego zajście i globalność;

- dużo mniejszy nacisk na doktrynę o młodej Ziemi. Nie wyklucza się jej, ponieważ w oczywisty sposób czyni ewolucję skrajnie nieprawdopodobną, a ponadto jest zgodna z poglądami wielu myślicieli arabskich doby klasycznej ${ }^{11}$, jednak nie jest też kluczowym punktem doktryny, ponieważ Koran

\footnotetext{
${ }^{10}$ Tamże, tłum. własne.

${ }^{11}$ Należy jednak pamiętać, że wpływowy filozof późnego średniowiecza, Ibn Chaldun, twierdził, iż życie wzięło początek od minerałów, które wyewoluowały w rośliny, a następnie zwierzęta. Uważał również, że ludzie mogli po-
} 
nie zawiera ścisłych danych o czasie stwarzania, w przeciwieństwie do Biblii mówiącej o sześciu dniach.

Co ciekawe, według relacji Pat Shipman ma miejsce zwrotna fala kreacjonizmu tureckiego w stronę USA, w postaci misjonarskich wizyt z odczytami na amerykańskich kampusach uniwersyteckich (Shipman wymienia uniwersytety Pittsburgh, Lehigh, Villanova, Temple, Buffalo oraz Albany $)^{12}$ i w muzułmańskich ośrodkach kultury.

Teoria ewolucji pozostaje w tureckich podręcznikach szkolnych, ale Sayin i Kence alarmują, że jest opisywana w nienaukowy, naiwny, łatwy do obalenia sposób, np. sugerujący, że zdaniem Darwina przetrwać powinny silne organizmy, a ginać słabe - tymczasem dinozaury i mamuty wyginęły, a dżdżownice mają się dobrze $^{13}$. W 1999 roku jedna z partii politycznych, Fazilet Partisi (Partia Cnoty), zaproponowała nawet Ustawę Antyewolucyjną, która zakazywałaby nauczania o ewolucji gatunków oraz spowodowałaby zebranie i zniszczenie wszystkich dzieł popierających teorię ewolucji w całym kraju.

Liderem ruchu kreacjonistycznego w Turcji jest Harun Yahya. Pod tym nazwiskiem ukazało się tak wiele książek i broszur, że uważa się, iż Yahya nie może być tylko jedną osobą, choć np. po wpisaniu w Wikipedii „Harun Yahya” następuje automatyczne przekierowanie do artykułu o Adnanie Oktarze ${ }^{14}$ - rzeczywiście prawdopodobnie to on $\mathrm{w}$ głównej mierze ponosi intelektualną odpowiedzialność za dzieła Haruna Yahyi, tj. zapewne kilku osób z BAVu. Choć nie jest to kluczowa sprawa z filozoficznego czy

wstać z małp człekokształtnych. Już po ogłoszeniu teorii Darwina Al-Afghani zaakceptował ją i nawet podkreślał, że prekursorami myśli ewolucyjnej byli muzułmanie. (Zob. Ü. Sayin, A. Kence, dz. cyt.).

${ }^{12}$ P. Shipman, „Turkish Creationist Movement Tours American College Campuses", Reports of the National Center for Science Education, 5, t. 26 (2006), <http://ncse.com/rncse/26/5/turkish-creationist-movement-toursamerican-college-campuses $>$, 14.02.2012.

${ }^{13}$ Zob. Ü. Sayin, A. Kence, dz. cyt.

${ }^{14}$ Zob. <http://tr.wikipedia.org/wiki/Harun_Yahya>, 14.02.2012. 
naukowego punktu widzenia, powszechnie komentuje się fakt, że Yahya-Oktar nie jest osobą o nieposzlakowanej opinii. Zanim rozpoczął publiczną działalność, wchodził w konflikt z prawem. Wpisując się w krajobraz lęku przed komunizmem z lat 80., kontynuuje politykę przekonywania o istnieniu sekularnego spisku, w którym uczestniczą syjoniści, masoni, komuniści, ateiści i zwolennicy ideologii darwinistycznej.

Sayin i Kence dokonali podsumowania poglądów pojawiających się w książkach Yahyi ${ }^{15}$ : życie na ziemi powstało prawdopodobnie w czasie Eksplozji Kambryjskiej; żaden gatunek nigdy nie wyewoluował z innego; ewolucja to największa mistyfikacja $\mathrm{w}$ dziejach, a dane naukowe tak naprawdę podważają teorię ewolucji i wskazują, że we wszystkich formach życia tkwi cel i projekt; tendencja do bronienia teorii ewolucji jest zideologizowana - stoja za nią pobudki materialistyczne, rasistowskie lub satanistyczne; ludzie są stworzeni na obraz Allaha, więc nie mogli wyewoluować z małp, które są niższym gatunkiem. Publikacje BAVu zawierają zafałszowane odniesienia i cytaty z książek, które przemawiają tak naprawdę na rzecz teorii ewolucji, ale nie są dobrze znane w Turcji oraz z czasopism naukowych. W ten sposób tworzą wrażenie, że takie tytuły, jak „Scientific American” czy „Nature” postulują wizję kreacjonistyczna. Koran bywa w publikacjach BAVu traktowany jako źródło wiedzy naukowej.

Wbrew pozorom islam nie jest skazany na wplątanie w wojnę przeciw teorii ewolucji. Udowadnia to, przynajmniej na polu teologii i hermeneutyki, jako że chyba nikt nie byłby w stanie wziąć odpowiedzialności za możliwe antyintelektualne radykalne decyzje polityków, Nidhal Guessoum, profesor American University of Sharjah (Zjednoczone Emiraty Arabskie). Guessoum jest świadomy, że muzułmanie sa przywiązani do wiary w pierwszego człowieka, Adama, i nie są skłonni ustąpić w kwestii absolutnej wyjątkowości człowieka wobec innych stworzeń. Ubolewa też nad tym, że duchowni ogłaszają fatwy ostrzegające przed ewolucjo-

${ }^{15}$ Zob. Ü. Sayin, A. Kence, dz. cyt. 
nizmem i przedstawiające go jako sprzeczne z religią ${ }^{16}$. Guessoumowi zależy na odróżnieniu teorii naukowych od ich interpretacji metafizycznych, a także na wyperswadowaniu współwyznawcom fałszywego przeciwstawienia faktów i teorii. Ewolucja życia na Ziemi trwająca przez miliony lat jest faktem, który może zostać wyjaśniony przez wiele teorii (dlatego ktoś, kto mówi „ewolucja jest tylko teorią, a nie faktem", miesza porządki, a niestety zdarza się to muzułmańskim autorytetom). Guessoum dopuszcza zatem, że tak, jak lamarkizm został zastąpiony przez darwinizm, a darwinizm był udoskonalany dzięki odkryciom z dziedziny genetyki, może i aktualny paradygmat zostanie znacząco zmodyfikowany. Nie mogą to być jednak koncepcje religijne zamiast naukowych ${ }^{17}$. Odrzucenie materialistycznej i czysto naturalistycznej metafizyki może się powieść dzięki stanowisku ewolucyjnego teizmu. Guessoum, który jest aktywny w środowisku science and religion na Zachodzie, docenia teologiczną recepcję teorii ewolucji dokonaną w XIX i XX w. przez chrześcijan (powołuje się między innymi na Keitha Warda, Johna Haughta, Arthura Peacocke'a, Johna Polkinghorne'a) $)^{18}$ i nie widzi potrzeby postulowania takich niedorzeczności epistemologicznych i edukacyjnych, jak Islamic Science według Seyyeda Hosseina Nasra ${ }^{19}$, co nie znaczy jednak, iż nie zastanawia się nad adaptacją ewolucyjnego teizmu do specyficznie muzułmańskiego punktu widzenia. Aby to uczynić, przywołuje fragmenty Koranu, które sugerują stwarzanie życia stopniowo i przez długi okres czasu, a także poglądy myślicieli klasycznego okresu filozofii arabskiej, przede wszystkim al-Farabiego, Ibn Miskawajha i Ibn Chalduna, którzy wyrażali przekonanie, że życie

${ }^{16}$ Zob. N. Guessoum, Islam's Quantum Question. Reconciling Muslim Tradition and Modern Science, I. B. Tauris, London-New York 2011, s. 274-275.

${ }^{17}$ Zob. tamże, s. 291-295.

${ }^{18}$ Zob. tamże, s. 297-299.

${ }^{19}$ Dla zwięzłego opisu idei Islamic Science zob. S.H. Nasr, „Islam and Science", [w:] P. Clayton, Z. Simpson (red.), The Oxford Handbook of Religion and Science, Oxford University Press, Oxford-New York 2009, s. 71-86; krytyka zob. N. Guessoum, dz. cyt., s. 101-140. 
wzięło początek z nieożywionej materii, a zwierzęta z roślin ${ }^{20}$. Guessoum opisuje też mało znany fakt: już w XIX w., niedługo po ukazaniu się dzieła $O$ pochodzeniu gatunków, uczeni muzułmańscy wdali się w dyskusję dotyczącą darwinizmu. „(...) stanowiska mieściły się w szerokim spektrum, od łatwego odrzucenia aż do akceptacji in toto. W rzeczy samej, niektórzy arabscy sekularyści dostrzegali w darwinizmie ucieleśnienie nowoczesnego naukowego ducha tamtego okresu oraz sposób na odciągnięcie arabskiego świata z powrotem od jego zacofanej i nieracjonalnej mentalności" ${ }^{21}$. Do dziewiętnastowiecznych myślicieli, którzy postulowali zgodność islamu z nauką, konieczność nieliteralnej interpretacji objawienia i naturalizm metodologiczny w nauce, należy zaliczyć przede wszystkim Husseina al-Dżisra i Mustafę H. al-Mansuriego. Guessoum udowadnia, że dzięki wysiłkowi hermeneutycznemu możliwe jest zmierzenie się z najtrudniejszym problemem - pochodzeniem ludzi. Komentując osiągnięcia Muhamada Szahrura w dziedzinie antropologii koranicznej, pisze:

(...) arabskie/koraniczne słowa insan, zwykle rozumiane jako „człowiek”, oraz baszar, najczęściej tłumaczone jako „istota ludzka”, muszą być rozróżniane; odnoszą się one do dwóch zupełnie różnych stadiów ludzkiej ewolucji. Rzeczywiście, badając historię Adama z Koranu, [Szahrur] pokazuje, że za każdym razem, gdy użyte jest słowo insan ( „człowiek”), pojawia się wyraźne skojarzenie z „rozumowaniem” (zdolnościami umysłowymi), ,abstrakcyjną koncepcję" (szczególnie bytów metafizycznych) oraz „inteligencją". Przeciwnie, wyraz baszar bywa używany wyłącznie w kontekście stwarzania, na długo zanim wyewoluował do insan i nabył zdolności umysłowych ${ }^{22}$.

Zarys wydarzeń związanych z kreacjonizmem w Europie zachodniej dobrze zacząć od ojczyzny Karola Darwina. Wielka Brytania boryka się $\mathrm{m}$. in. z edukacyjnym aspektem sprawy, ponieważ,

\footnotetext{
${ }^{20}$ Zob. tamże, s. 303-308.

${ }^{21}$ Tamże, s. 308-309, tłum. własne.

${ }^{22}$ Tamże, s. 313, tłum. własne.
} 
o ile w Narodowym Programie Nauczania (National Curriculum) nie ma miejsca dla kreacjonistycznego punktu widzenia, o tyle kwestia staje się problematyczna, gdy chodzi o szkoły finansowane niezależnie (lub tylko częściowo z budżetu państwa) oraz szkoły wyższe. "Current Biology” donosi o przypadku Emmanuel College w Gateshead, gdzie jeden z prywatnych sponsorów, ewangeliczny chrześcijanin, postanowił przenieść swoje poglądy na treści nauczania, co - gdy tylko wyszło na jaw - wzbudziło zdecydowany protest $\mathrm{m}$. in. Richarda Dawkinsa, Petera Atkinsa i Steve'a Jonesa $^{23}$. Julian Joyce z BBC wskazuje podobny przypadek cenionej szkoły, która naucza kreacjonizmu jako nauki, tj. Islamic Karimia Institute w Nottingham ${ }^{24}$. Gdy decentralizacja edukacji i homeschooling w niektórych państwach stają się lekarstwem na napięcia spowodowane imigracją i wielokulturowością, a w innych (np. w Australii) od dawna funkcjonują jako jedyna rada wobec niezbyt gęstego zaludnienia lub są narzędziem wyrównywania szans edukacyjnych $^{25}$, zapewne czas na przemyślenie ostrzeżenia Roberta Pennocka, który w swoim artykule dotyczącym nauczania kreacjonizmu w szkołach pyta o to, jaka jest filozofia edukacji współczesnych społeczeństw i jej priorytety. Jeżeli na pierwszym miejscu umieścimy możliwie najlepsze poznanie świata, to trudno nam będzie udzielić miejsca poglądom religijnym na przedmiotach, które nazywają się „biologia”, „nauki ścisłe” albo „przyroda”, nawet jeśli nie musimy wykładać na to podatków ${ }^{26}$. W artykule Joyce'a jest dalej mowa o Genesis Expo, muzeum założonym przez najstar-

${ }^{23}$ Zob. M. Gross, „US-style Creationism Spreads to Europe”, Current Biology, 8, t.12 (2002), s. 265.

${ }^{24}$ Zob. J. Joyce, Who are the British Creationists?, 15.09.2008, <http://news.bbc.co.uk/2/hi/7613403.stm>, 14.02.2012.

${ }^{25}$ Por. J. Lackowski, Decentralizacja zarzadzania polskim systemem oświatowym a spoleczne nierówności edukacyjne, Wydawnictwo Uniwersytetu Jagiellońskiego, Kraków 2008.

${ }^{26}$ Zob. R.T. Pennock, „Why Creationism Should Not Be Taught in the Public Schools?", [w:] R.T. Pennock (red.), Intelligent Design Creationism and its Critics: Philosophical, Theological, and Scientific Perspectives, MIT Press, Cambridge (MA)-London 2001, s. 756. 
szą brytyjską grupę kreacjonistyczną, Creation Science Movement, podobnym do amerykańskiego Creation Museum. Prześledzenie komentarzy internautów do w/w tekstu okazuje się pouczające. Przykładowo, Martin z Bradford pisze, że ewolucjonistów zaślepia nienaukowa przesłanka o nieistnieniu Boga oraz że ewolucjonizm jest tylko poglądem, systemem wierzeń. Andre z Londynu, który opisuje siebie jako nowo narodzonego (born again) chrześcijanina, usiłuje osłabić roszczenia nauki, pisząc: „(...) ale czy wszystko, czego w życiu doświadczamy, zarówno fizycznie, jak i emocjonalnie, może być dowiedzione przez naukę?” i dodaje: „Próbować udowadniać, że człowiek wyewoluował od małp, bo mogą tam być pewne podobieństwa, to jak próbować udowodnić, że kolibry wyewoluowały z helikopterów, ponieważ i te, i tamte latają"27. Ów pierwszy komentarz wpisuje się w szerszy nurt wątpliwości: często można bowiem usłyszeć w odniesieniu do paradygmatu ewolucyjnego: „To tylko teoria”. Osoba wypowiadająca się w ten sposób niemal na pewno korzysta z potocznego rozumienia teorii jako poglądu nieudowodnionego, hipotetycznego, stronniczego. Howard Van Till w tekście o interpretacji procesu ewolucji jako stworzenia, przyznaje, że w paradygmacie ewolucyjnym istnieją luki i zagadki (nie potrafimy odtworzyć w nieprzerwany sposób dziejów powstawania gatunków), ale jednocześnie przypomina podstawowe wnioski filozofów nauki, które wyprowadzają z błędu lekceważenia teorii:

Zatem epizodyczny kreacjonista technicznie ma rację, mówiąc, że istnieją takiego rodzaju poznawcze luki, które zagradzają nauce drogę do ogłoszenia, że szczegółowa teoria ewolucji życia została «udowodniona» w ścisłym logicznym znaczeniu tego słowa. (...) Celem jest raczej skonstruowanie ujęcia teoretycznego, które w kontekście wszelkich dostępnych istotnych danych empirycznych oraz w granicach pewnych przesłanek dotyczących charakteru Wszechświata

${ }^{27}$ Zob. J. Joyce, dz. cyt. 
i dziejów jego formowania się, będzie najbardziej adekwatnym stanowiskiem do utrzymania w danym czasie $^{28}$.

Czytając „Telegraph” z 31 stycznia 2009, można zacząć dociekać, czy przypadkiem co drugi Brytyjczyk nie popiera teorii Inteligentnego Projektu. W artykule Jonathana Wynne-Jonesa czytamy bowiem, że 51\% osób bioracych udział w badaniu ComRes dla think-tanku Theos zgodziło się ze zdaniem „Sama ewolucja nie wystarczy, by wyjaśnić złożoną strukturę niektórych istot żywych, więc interwencja projektanta jest potrzeba w kluczowych stadiach" ${ }^{29}$. Ciekawego komentarza udzielił dyrektor Theosu, Paul Wooley: „Darwin jest używany przez niektórych ateistów do promowania ich sprawy. Rezultat jest taki, że stojąc przed fałszywym wyborem między ewolucją a Bogiem, ludzie odrzucają ewolucje" 30 . Roy Clouser w artykule poświęconym Księdze Rodzaju zauważa, że teiści wcale nie muszą dokonywać takiego fałszywego wyboru, lecz są w stanie zinterpretować każdą prawdziwie naukową teorię w duchu wiary. Filozof przypomina sformułowany przez Augustyna pogląd, że Bóg nie stwarzał świata w czasie, bo sam czas musiał być dopiero stworzony i dlatego nie należy się przywiązywać do biblijnej koncepcji sześciu dni stworzenia ${ }^{31}$. Zdaniem Clousera osią tożsamości teistycznej nie jest żadna konkretna opinia na temat sposobu ani czasu trwania stwarzania, lecz raczej wiara w fundamentalną zależność wszystkiego, co istnieje, od Boga oraz nie-boską naturę stworzeń ${ }^{32}$.

Wielu kreacjonistów europejskich to mieszkańcy krajów niemieckojęzycznych. Szwajcarski portal swissinfo.ch przywołuje sta-

\footnotetext{
${ }^{28}$ H.J. Van Till, „The Creation: Intelligently Designed or Optimally Equipped", [w:] R. T. Pennock [red.], dz. cyt., s. 495, tłum. własne.

${ }^{29}$ J. Wynne-Jones, „Poll Reveals Public Doubts over Charles Darwin's Theory of Evolution", The Telegraph, 31.01.2009, <http://www.telegraph.co.uk/news/religion/4410927/Poll-reveals-publicdoubts-over-Charles-Darwins-theory-of-evolution.html>, 14.02.2012.

${ }^{30}$ Tamże, tłum. własne.

${ }^{31}$ Zob. R. Clouser, „Is Theism Compatible with Evolution?”, [w:], R.T. Pennock (red.), dz. cyt., s. 517.

${ }^{32}$ Tamże, s. 528 .
} 
tystyki wedle których $30 \%$ Szwajcarów sprzeciwia się teorii ewolucji, a $80 \%$ chciałoby nauczania w szkołach kreacjonizmu obok teorii ewolucji ${ }^{33}$. Eksperci, którzy udzielili portalowi wywiadu, wskazują, że globalizacja, która oznacza swobodne przemieszczanie informacji, sprzyja poczuciu niepewności oraz że krytyczna pozycja wobec nauki wypływa z przekonania, iż jest ona wyprana z sensu życia ${ }^{34}$. Szwajcarzy martwią się też o stan własnej edukacji i zmysł krytycznego myślenia: „W rzeczy samej szwajcarski system demokracji bezpośredniej jest szczególnie narażony na niezdolność do oddzielania faktu od fikcji” ${ }^{35}$. Zdaniem Sebastiana Boenhoffera, profesora biologii z Federalnego Instytutu Technologii w Zurychu, rozważanie przyczyn powodzenia kreacjonizmu wśród części jego rodaków powinno obracać się nie wokół problemu dialogu między religią a nauką, lecz przerodzić się w pytanie o umiejętność kształtowania własnych opinii w oparciu o dane: „Sądzę, że [sondaż] odzwierciedla kiepską edukację. (...) Z pewnością jest grupa, której się nie da przekonać [o ewolucji], jednak myślę, że istnieje też spora wspólnota, która mogłaby zostać przekonana, gdyby była nauczona, jak oceniać dane" 36 . Powyższa diagnoza mieści się w szerszej perspektywie edukacyjnej i skłania do ponownej oceny stanu nie tylko przyrodoznawczego, ale także filozoficznego i teologicznego nauczania. Jak podkreśla Van Till, wiara w to, że świat został zaprojektowany czy też - mówiąc jego słowami - przemyślany (thoughtfully conceptualized), zupełnie nie implikuje poglądu, że nie został wyposażony w potencjał tworzenia nowych form. Tymczasem jeden z czołowych przedstawicieli ruchu Inteligentnego Projektu, Phillip Johnson, przekonywał w swojej

${ }^{33}$ D. Bechtel, Creationism controversy evolves, 28.11.2007, $<$ http://www.swissinfo.ch/eng/Home/Archive/Creationism_controversy_evolves.html?cid=6283640>, 15.02.2012.

${ }^{34}$ Zob. tamże.

${ }^{35}$ T. Stephens, Swiss drag knuckles accepting evolution, 09.10.2006, $<$ http://www.swissinfo.ch/eng/Home/Archive/Swiss_drag_knuckles_accepting_evolution.html?cid=70292>, 15.02.2012; tłum. własne.

${ }^{36}$ Zob. , tłum. własne. 
książce Darwin on Trial ${ }^{37}$, że teistyczne spojrzenie na ewolucję nie jest możliwe, ponieważ ewolucjonizm i silny metafizyczny naturalizm są nieodłączne ${ }^{38}$. Van Till zauważa, że stawia to apologetów w kłopotliwej sytuacji, w której tańczą tak, jak materialiści zagrają: „Obie strony popularnej debaty oczywiście kategorycznie nie zgadzają się co do tego, czy mocna zasada formacyjnej ekonomii jest prawdziwa, jednak mimo to wydaje się, że są zgodni, iż jeśli jest prawdziwa, to naturalizm wygrywa albo przynajmniej okazuje się bardziej prawdopodobny niż chrześcijański teizm" 39 . Teizm ewolucyjny zdaje się skutecznie unikać tego niebezpieczeństwa, odróżniając osiągnięcia nauki od materialistycznych założeń metafizycznych oraz akceptując jedynie te pierwsze.

Dwa najbardziej znane stowarzyszenia antyewolucjonistyczne w kręgu niemieckojęzycznym to Pro Genesis i Studiengemeinschaft Wort und Wissen. Propagują swoje idee poprzez materiały audiowizualne oraz czasopisma „Factum” i „Studium Integrale Journal". Ulrich Kutschera, zaangażowany niemiecki antykreacjonista, podjął się krótkiego omówienia ${ }^{40}$ wpływowego dzieła Evolution: Ein kritisches Lehrbuch ${ }^{41}$ zredagowanego przez pracownika Wort und Wissen, Reinharda Junkera oraz członka Discovery Institute, Siegfrieda Scherera. Podręcznik, który promuje sprzeciw wobec koncepcji makroewolucji, zawiera nową propozycje podziału taksonomicznego. Zdaniem Kutschery inspiracja Junkera i Scherera była czysto biblijna, nawiązująca do słów o stwarzaniu roślin i zwierząt „według ich rodzaju”, które kilkakrotnie powtarzają się

${ }^{37}$ P. Johnson, Darwin on Trial, InterVarsity Press, Downers Grove 1991.

${ }^{38}$ Zob. H. J. Van Till, dz. cyt., s. 503. Informację o poglądach Johnsona przytaczam za Van Tillem, chodzi o dzieło: P. Johnson, Darwin on Trial, dz. cyt.

${ }^{39}$ Tamże, s. 504, tłum. własne.

${ }^{40} \mathrm{U}$. Kutschera, „Darwinism and Intelligent Design: The New AntiEvolutionism Spreads in Europe", Reports of the National Center for Science Education, 5-6, t. 23 (2003), <http://ncse.com/rncse/23/5-6/darwinismintelligent-design-new-anti-evolutionism-spreads-e $>, 15.02 .2012$.

${ }^{41}$ R. Junker, S. Scherer, Evolution: ein kritisches Lehrbuch, Weyel, Gießen 2006. 
w Księdze Rodzaju. Podręcznik postuluje istnienie właśnie takich „rodzajów” jako wyższych grup taksonomicznych, które autorzy nazwali Podstawowymi Typami. „Jako przykłady Junker i Scherer omawiają następujące Typy Podstawowe: Anatidae (kaczki, gęsi i łabędzie), Canidae (psy, wilki i lisy), Triticeae (pszenica, jęczmień i owies) oraz ludzie (jeden gatunek, Homo sapiens). Ta nowatorska «teoria oparta na Biblii» postuluje, że Bóg stworzył zdolność różnicowania wbudowaną w każdy rodzaj, ale nie pomiędzy różnymi Typami Podstawowymi" ${ }^{42}$. Zdaniem Kutschery fakt, że międzynarodowe czasopismo „Flora” redagowane przez uznanych botaników opublikowało pozytywną recenzję tej książki, świadczy, iż kreacjoniści przenikają skutecznie do kręgów akademickich.

Wort und Wissen wyprodukowało w 1998 roku film z udziałem Scherera zatytułowany „Hat die Bibel doch recht? Der Evolutionstheorie fehlen die Beweise". Pada w nim m. in. stwierdzenie, że na makroewolucję nauka nie znalazła żadnych dowodów, a Darwina i Haeckla opisuje się jako duchowych ojców Holokaustu ${ }^{43}$. Niemcy musieli się też zmierzyć z poparciem dla kreacjonizmu płynącym z góry, tj. z resortu edukacji. W październiku 2006 ówczesna minister edukacji w Hesji, Karin Wolff, wyraziła pogląd, że teoria stworzenia powinna być nauczana na lekcjach biologii jako teoria, podobnie jak teoria ewolucji ${ }^{44}$. Na przykładzie niemieckich mediów można wskazać pewną dezinformację w obszarze kontrowersji ewolucjonizm versus kreacjonizm. Artykuł Jensa Lubaddeha w internetowym wydaniu „Spiegel” myli, co jest jeszcze dość łatwo wybaczyć, Romana Giertycha z Maciejem Giertychem oraz, co jest już poważnym błędem, teizm ewolucyjny z Inteligentnym Projektem (przez co czytelnik może odnieść wrażenie,

\footnotetext{
${ }^{42}$ U. Kutschera, dz. cyt., tłum. własne.

${ }^{43} \mathrm{U}$. Kutschera, „The German Anti-Darwin Industry", Reports of the National Center for Science Education, 1, t. 28 (2008), <http://ncse.com/rncse/28/1/german-anti-darwin-industry>, 15.02.2012.

${ }^{44}$ Zob. German Scientists Concerned About Rise in Creationist Belief, 02.11.2006, <http://www.dw.de/dw/article/0,22222454,00.html>, 15.02.2012.
} 
że Kościół Rzymskokatolicki promuje ID), a przy tym jest nieco scjentystyczny w swej ogólnej wymowie ${ }^{45}$.

Kreacjonizm w Rosji utorował sobie drogę dzięki przemianom politycznym, podobnie jak wersja turecka. Po upadku ZSRR calkowita świeckość przestała być edukacyjnym dogmatem, a do Rosji przeniknęły misje rozmaitych Kościołów i wspólnot ewangelicznych oraz pentekostalnych. Kościoły prawosławne czasem również przejawiają tendencje do faworyzowania antyewolucjonistycznego punktu widzenia. Szersza publiczność dowiedziała się o napięciach w sferze edukacyjnej przy okazji nagłośnienia przez media pozwu uczennicy szkoły średniej, Marii Schreiber, przeciw ministerstwu edukacji oraz Siergiejowi Mamontowi, autorowi podręcznika do nauczania biologii, w którym znalazło się zdanie nazywające biblijną historię stworzenia „mitem” 46 . Schreiber zażądała nie tylko przeprosin, ale również pozwolenia na nauczanie koncepcji alternatywnych dla teorii ewolucji. Ówczesny rosyjski minister edukacji, Andriej Fursenko, dość przychylnie odniósł się do pomysłu nauczania alternatywnych idei, a Patriarcha Moskwy i Wszechrusi, Aleksiej II niedługo przed wydaniem wyroku powiedział na wykładzie w Kremlu: „Ci, którzy chcą wierzyć, że wywodzą się od małp, mogą to robić, ale nie mogą narzucać własnej opinii innym"47. Patriarcha posłużył się tu oczywiście obiegowym i nieprecyzyjnym stwierdzeniem („ludzie pochodzą od małp"), ale nie na tym chciałam się skupić. Zadam raczej pytanie: czy na pewno chodzi o opinię? Jeżeli uznajemy, że przedsięwzięcia naukowe mają cel poznawczy oraz cokolwiek wspólnego z poznawaniem intersubiektywnej prawdy za pomocą rygorystycznie

\footnotetext{
${ }^{45}$ Zob. J. Lubaddeh, „Contesting Evolution: European Creationists Take on Darwin", Spiegel Online, 25.02.2009, <http://www.spiegel.de/international/zeitgeist/0,1518,609712,00.html>, 15.02.2012.

${ }^{46}$ Zob. I. Levit, U. Hoßfeld, L. Olsson, „Creationism in the Russian Educational Landscape", Reports of the National Center for Science Education, 5-6, t. 27 (2007), <http://ncse.com/rncse/27/5-6/creationism-russian-educationallandscape $>, 16.02 .2012$.

${ }^{47}$ Tamże, tłum. własne.
} 
ocenianych i doskonalonych metod, to nie możemy sprowadzać dyskursu naukowego do arbitralnych opinii. Zgadzam się w tej kwestii z Pennockiem, który odpiera zarzut Johnsona ukazujący blokowanie inteligentnego projektu w szkołach jako dyskryminację ze względu na poglądy. Johnson opiera się na orzeczeniu Sądu Najwyższego Stanów Zjednoczonych w sprawie Lamb's Chapel przeciw Center Moriches Union Free School District z roku 1993 (sąd orzekł, że niedopuszczenie do pokazania uczniom przygotowanego przez jeden z Kościołów filmów o rodzinie i wychowaniu dzieci pogwałciło zapisy o wolności słowa z Pierwszej Poprawki), co wydaje się mocnym argumentem. Pennock jednak zauważa, że nie można sprawy stylu życia, etyki rodzinnej czy modeli ról społecznych porównywać do sporów z dziedziny nauk empirycznych $^{48}$.

Na rosyjskim rynku wydawniczym funkcjonują podręczniki biologii propagujące kreacjonizm. Te najnowsze mogą być uznane za atrakcyjne z wielu powodów: bywają ładnie wydane i ilustrowane, naśladują układ świeckich książek oraz spełniają większość rosyjskich standardów edukacyjnych. Jako typowy przykład Inga Levit, Uwe Hoßfeld i Lennart Olsson podaja Biologie ogólna dla 10-11 lat szkót zwyczajnych z nauczaniem biologii na fundamencie prawosławia ${ }^{49}$ Siergieja Jurewicza Wertjanowa z 2005 roku. Różnice między „prawosławnymi” 50 a świeckimi poglądami na powstawanie gatunków i inne zagadnienia przyrodnicze są wyjaśniane jedynie na końcu rozdziałów. Niemniej, Wertjanow utrzymuje, że dinozaury żyły równolegle ze starożytnymi ludźmi oraz usiłuje zrekonstruować idealny łańcuch pokarmowy w świecie sprzed upadku pierwszych ludzi ${ }^{51}$, co wydaje się kuriozalne. Pod-

\footnotetext{
${ }^{48}$ Zob. R. T. Pennock, dz. cyt., s. 768.

${ }^{49}$ С.»Ю Вертьянов, Общая биология, Свято-Троицкаа Лавра, Москва 2005.

${ }^{50}$ To słowo zasługuje na cudzysłów, ponieważ Kościoły prawosławne nie mają wyłącznie jedynej oficjalnej doktryny na temat teorii ewolucji i prowadzą także dyskurs teistycznego ewolucjonizmu. Wertjanow ma więc wąską wizję tego, co jest prawosławne.

${ }^{51}$ Zob. I. Levit, U. Hoßfeld, L. Olsson, dz. cyt.
} 
ręcznik nie jest rekomendowany przez ministerstwo, ale używano go zarówno w szkołach prywatnych (np. Jaseniewo i Saburowo w Moskwie), jak i państwowych (np. Szkoła nr 262 w Moskwie) ${ }^{52}$.

Jeszcze inny obraz kreacjonizmu w Rosji otrzymujemy, czytając relację współtwórców całego zamieszania, Institute for Creation Research, z odnoszonych sukcesów. John i Swietłana Doughty wspominają, jak jeszcze w latach 80. szmuglowano do Rosji książki Henry'ego Morrisa i jak kreacjoniści szli w awangardzie wolności obywatelskich w okresie transformacji. W 1995 kilku członków ICR uczestniczyło w obradach z udziałem przedstawicieli rosyjskiego ministerstwa edukacji, którzy mieli poszukiwać pomocy w układaniu programu nauczania zawierającego creation science $^{53}$. Przekłady publikacji kreacjonistycznych, wśród nich The Scientific Case for Creation ${ }^{54}$, The Bible Has the Answer ${ }^{55}$ czy Biblical Basis for Modern Science ${ }^{56}$, ukazywały się nakładem wydawnictw protestanckich - Slavic Gospel Association, Protestant Publishing House oraz Bible for Everyone Company. ICR postrzega sens własnej misji w Rosji bardzo szeroko:

Ukazywanie dowodów stworzenia było, jest i pozostanie najważniejszym zadaniem w odradzającej się Rosji. Działania Marksa, Lenina i Stalina, ewolucjonizm których usunął Boga ze społeczeństwa, zaowocował «Imperium zła» Związku Radzieckiego (1917-1991). Upadek komunizmu przyniósł nowo ustanowioną wolność, jednak wytworzył duchową próżnię, która nadal czeka na wypełnienie. Kre-

${ }^{52}$ Zob. tamże.

${ }^{53} \mathrm{Nie}$ potrafię $\mathrm{w}$ tej chwili zweryfikować podanej informacji. Odsyłam do źródła: J. Doughty, S. Doughty, Creationism in Russia, <http://www.icr.org/article/creationism-russia/>, 16.02.2012.

${ }^{54}$ Tutaj i w kolejnych dwóch przypisach podaję wydania anglojęzyczne: B. Thompson, The Scientific Case for Creation, Apologetics Press, Montgomery 1986.

${ }^{55}$ H.M. Morris, M.E. Clark, The Bible Has the Answer, Master Books, Green Forest 1976.

${ }^{56}$ H.M. Morris, The Biblical Basis for Modern Science, Master Books, Green Forest 1984. 
acjonizm jest fundamentem prawdziwego chrześcijaństwa

i jest niezbędny dla sukcesu jakiegokolwiek kraju ${ }^{57}$.

W innym kraju prawosławnym, Serbii, w 2004 roku miał miejsce incydent z udziałem ministerstwa edukacji. Ljiljana Colič, minister edukacji, zaproponowała, aby pokazać, że należy nauczać różnych teorii dotyczących życia na Ziemi, poprzez roczny zakaz nauczania teorii ewolucji. Powiedziała też, że „Zarówno darwinowska teoria doboru naturalnego, jak i starotestamentalny pogląd na początki życia, są tak samo dogmatyczne" ${ }^{58}$. Pojawiły się opinie sugerujące, że propozycja pani minister wskazuje na wmieszanie Serbskiego Kościoła Prawosławnego w politykę. Nawet jeśli tak było, stanowisko Kościoła z pewnością nie jest monolityczne, gdyż serbski biskup Ignjatije publicznie podkreślił, że popiera pozostawienie teorii ewolucji w programach nauczania oraz docenia wiedze o ścisłym połączeniu człowieka z innymi formami życia ${ }^{59}$. Colič zastosowała strategię znaną z działalności kreacjonistów w USA, czyli przedstawianie ewolucjonizmu jako fundamentalistycznej ideologii przy jednoczesnym stosowaniu wyrażenia creation science na oznaczenie własnego stanowiska. U Pennocka możemy znaleźć przydatne wyliczenie innych jeszcze argumentów, które być może zaczną zdobywać zwolenników w krajach, do których kreacjonizm zawitał niedawno: prawo rodziców do decydowania, czego powinny uczyć się dzieci, reguła większości, wolność myśli naukowej, sprzeciw wobec cenzury ${ }^{60}$. Są to wartości rzadko kwestionowane w demoliberalnych społeczeństwach, dlatego warto zastanowić się, jak wskazać ewentualne ich nadużycia. Reguła większości staje się absurdalna, gdy przeradza się w głosowanie nad prawdą lub fałszem. Podobnie jest z prawami rodziców, którzy niekoniecznie są specjalistami w dziedzinie nauk przyrodniczych (oczywiście

\footnotetext{
${ }^{57}$ Zob. J. Doughty, S. Doughty, dz. cyt., tłum. własne.

${ }^{58}$ Serbia Reverses Darwin Suspension, 09.09.2004, <http://news.bbc.co.uk/2/hi/europe/3642460.stm>, 16.02.2012; tłum. własne.

${ }^{59}$ Zob. tamże.

${ }^{60}$ Zob. R. T. Pennock, dz. cyt., s. 766.
} 
zupełnie inną kwestią jest decydowanie rodziców w materii edukacji obywatelskiej, seksualnej, religijnej itp.). Cenzura wydaje się zbyt szerokim pojęciem, którego można by użyć, gdyby chodziło o zakaz propagowania kreacjonizmu/ID w mediach, na szkółkach niedzielnych itd. Najwięcej kłopotu sprawia chyba argument z akademickiego nieskrępowania myśli. Pennock przypomina, że organizacje kreacjonistyczne w USA nieraz dążyły do usunięcia teorii ewolucji ze szkół, nie widząc w tym większego zagrożenia dla wolności nauki ${ }^{61}$, ja natomiast pozwolę sobie dodać, iż na polu akademickim powinni się zmagać biolodzy, którzy są w stanie skonfrontować metodologie, wyniki badań genetycznych i skamieliny, nie zaś uczniowie szkół podstawowych i średnich wraz z lokalnymi pastorami.

Wraz z chrześcijańskimi aktywistami kreacjonizm zawitał do Azji (ten aspekt misjonarstwa nieczęsto bywa poruszany, ale to temat na odrębną pracę). Na stronie ICR możemy znaleźć entuzjastyczny tekst o sukcesach w Korei Południowej. Najbardziej godne podkreślenia wydaje mi się to, że ów koreański kreacjonizm nabrał „oficjalnego" uniwersyteckiego kolorytu, mimo iż chrześcijanie stanowią mniejszość. Założyciele ICR gościli w Seulu w roku 1980 na konferencji „Stworzenie czy ewolucja?”. Obrady zaowocowały zorganizowaniem Koreańskiego Towarzystwa Badania Stworzenia 31 stycznia 1981. Po piętnastu latach działalności miało ono szesnaście oddziałów krajowych i trzy zagraniczne filie, a członkami zostało ok. 500 osób z tytułem co najmniej doktora ${ }^{62}$. W 1991 roku Creation Science została wprowadzona przez Woongsanga Lee jako kurs akademicki na Uniwersytecie Myungjee. Wg danych podawanych przez ICR, na innych uczelniach również realizowano projekty w ramach dyskursu kreacjonistycznego, np. Analiza studiów dotyczacych pochodzenia ludzkości z punktu widzenia kreacjonisty na Wydziale Biologii Uniwersytetu Junnam

${ }^{61}$ Zob. tamże.

${ }^{62} \mathrm{C}$. Hyon, The Creation Science Movement in Korea, http://www.icr.org/article/creation-science-movement-korea, 16.02.2012. 
czy też Bład uniforminarianizmu na Wydziale Nauk o Ziemi Uniwersytetu Kongju ${ }^{63}$.

W Hong Kongu kwestia kreacjonizmu stała się popularna przy okazji układania planu nauczania biologii w roku 2009. W roboczej wersji planu pojawiło się kontrowersyjne zdanie: „Uczniowie są zachęcani, aby obok teorii Darwina poznawać inne wyjaśnienia ewolucji i początków życia, aby wspomóc zobrazowanie dynamicznej natury wiedzy naukowej” 64 . Aż trzydzieści szkół w Hong Kongu, które są dotowane przez państwo, ale administrowane przez niezależne organizacje, często religijne, przemyca Inteligentny Projekt do treści nauczania. Po proteście naukowców z Uniwersytetu w Hong Kongu, wspomaganych przez NCSE oraz 700 uczonych z całego świata, który otarł się o Radę Prawną Zespołu ds. Edukacji, zablokowano próby wprowadzenia ID do szkół, jednak nie bez przeszkód, gdyż w czasie tej potyczki uaktywniła się tzw. Grupa Sześćdziesięciu Czterech, która również lobbowała na Zespół ds. Edukacji, odwołując się do poglądu, iż Eksplozja Kambryjska podważa ewolucję oraz do porzucenia naturalizmu metodologicznego w naukach o życiu ${ }^{65}$. Chciałabym w tym miejscu zwrócić uwagę, jak użycie liczby mnogiej („inne wyjaśnienia”) specyficznie ustawia problem. Czy oznacza to różnego rodzaju wyjaśnienia, również pochodzące z mitów i ksiąg świętych? Jeżeli tak, to w państwach/regionach wielowyznaniowych, a takim z pewnością Hong Kong jest, stwarza to dodatkowe komplikacje spowodowane po prostu tym, że każda religia rozwinęła własną narrację na temat prapoczątków świata, życia i ludzi. Zajmowanie lekcji biologii ich omawianiem z pewnością mogłoby wzbudzać zakłopotanie, a o tym, że nie jest to wydumany problem, świadczy ponownie doświadczenie amerykańskie, gdzie mieszka chociażby

\footnotetext{
${ }^{63}$ Zob. tamże.

${ }^{64} \mathrm{~V}$. Yue, "A Creationism Row in Hong Kong", Reports of the National Center for Science Education, 6, t. 29, (2009), <http://ncse.com/rncse/29/6/creationism-row-hong-kong>, 17.02 .2012 ; tłum. własne.

${ }^{65}$ Zob. tamże.
} 
sporo członków Ruchu Raëliańskiego, którzy wierzą, że życie na Ziemi zostało stworzone przez kosmitów na drodze inżynierii genetycznej (wyrażenie „inteligentny projekt” nabiera tu dodatkowego kolorytu) i bynajmniej nie stronią od zaangażowania w sferze publiczno-obywatelskiej. Obok tego przykładu Pennock relacjonuje kontrowersję wokół szkieletu z Kennewick, który niemal przywłaszczyło sobie plemię Rdzennych Amerykanów, Umatilla, z zamiarem natychmiastowego pochówku, rozpoznając w nim szczątki swego przodka. Pomimo dobrze uzasadnionych podejrzeń naukowców, że szkielet należał raczej do osoby rasy białej, przedstawiciele plemienia byli pewni swoich racji, ponieważ wierzenia religijne Umatilla zakładają, że ich lud został stworzony przez Boga jako pierwszy ${ }^{66}$.

„Niewiele krajów poza Stanami Zjednoczonymi przywitało kreacjonizm cieplej niż Australia" - takiego zdania nie waha się wypowiedzieć Numbers ${ }^{67}$. Pod koniec lat 70 . założona została Creation Science Foundation z siedzibą w Brisbane. W 2005 roku australijski minister edukacji, Brendan Nelson, poparł zapoznawanie uczniów zarówno z ewolucją, jak i Inteligentnym Projektem: „Jeśli chodzi o moją opinię, uczniowie mogą być nauczani i powinni być nauczani podstaw nauki dotyczących ewolucji człowieka, ale jeśli szkoły chcą także prezentować uczniom Inteligentny Projekt, nie widzę w tym żadnego problemu. Tu chodzi o wybór, rozsądny wybór" 68 . W 1992 powstało nowozelandzkie skrzydło CSF, Creation Science (New Zealand), które krzewi kreacjonizm także wśród wyspiarzy Pacyfiku i Maorysów ${ }^{69}$.

Mało znana jest afrykańska odmiana antyewolucjonizmu, tymczasem w RPA, gdzie od dawna sięgają wpływy kultury zachodniej, trzy główne Kościoły Reformowane, wywodzące się z tradycji

\footnotetext{
${ }^{66}$ R. T. Pennock, dz. cyt., s. 760.

${ }^{67}$ R. Numbers (red.), Galileo Goes To Jail. ., dz. cyt., 216.

${ }^{68} \mathrm{D}$. Wroe, Intelligent design an option: Nelson, 11.08.2005, <http://www.theage.com.au/articles/2005/08/10/1123353386917.html>, 17.02.2012; tłum. własne.

${ }^{69}$ Zob. R. Numbers (red.), Galileo Goes To Jail..., dz. cyt., s. 217.
} 
holenderskiej, miały ambicje powstrzymać wpływy brytyjskiej „liberalnej” edukacji, a kontrowersje trwają przynajmniej od stu lat. Zderzenie kultur i ras w Afryce południowej rodziło pytania o ewentualne wspólne pochodzenie Białych i Czarnych - oczywiście tym pierwszym wydawało się to trudne do przyjęcia ${ }^{70}$. W latach 20. i 30. Johannes de Plessis, ważny teolog w seminarium Nederduits Gereformeerde Kerk na Uniwersytecie Stellenbosch, wyłamał się z nurtu kreacjonistycznego i postanowił propagować darwinistyczny punkt widzenia. Spotkała go za to suspensa i relegowanie ze stanowiska, a synod NGK uznał ewolucję za herezję. Dziś Kościoły kalwińskie w RPA raczej wycofały się z dawnej ideologii, choć starsze pokolenie nadal ma trudności z akceptacją teorii ewolucji ${ }^{71}$. Szczególną rysą na reputacji kreacjonistów w tamtym rejonie świata jest wspomnienie okresu walki z apartheidem, kiedy to ewolucjonistów uważano za wrogów starego „dobrego" konserwatywnego porządku. Mimo to RPA obmywa druga fala kreacjonizmu, związana ze wzrostem popularności Kościołów charyzmatycznych.

Zamiast podsumowania - gdyż jedynie z wielką trudnością można w kilku słowach podsumować globalne zjawisko - pozwalam sobie wyłuszczyć dwa problemy, którym warto przyjrzeć się w przyszłości. Pierwszy z nich to kreacjonizm w Polsce. Choć nasz kraj ze względu na względną homogeniczność wyznaniową nie wydaje się podatny na kontrowersję kreacjonistyczną, powstało Polskie Towarzystwo Kreacjonistyczne, a wydawnictwo Megas powoli dokonuje pewnych przekładów na polski. Gdyby doszło nad Wisła do poważniejszych publicznych batalii na tym tle, na pewno interesujące byłoby śledzenie ewentualnych pozwów i argumentów prawniczych oraz porównywanie ich z orzeczeniami amerykańskimi. Druga kwestia to recepcja problemu kreacjoni-

\footnotetext{
${ }^{70}$ Zob. L. W. Retief, „Calvin Meets the Hominins: A Brief History of Creationism in South Africa", Reports of the National Center for Science Education, 4, t. 28 (2008), <http://ncse.com/rncse/28/4/calvin-meets-hominins-briefhistory-creationism-south-africa $>, 17.02 .2012$.

${ }^{71}$ Zob. tamże.
} 
zmu i Inteligentnego Projektu w mediach. Wyżej już wskazałam pewne pomyłki, z pewnością jest ich więcej, a jeśli wziąć pod uwagę Internet i żartobliwo-polemiczną oddolną inicjatywę jego użytkowników, widzimy prawdziwy ocean nieporozumień, obelg, insynuacji i pseudoteologii. Cóż pozostaje, jeśli nie analiza?

\section{Bibliografia}

1. Bechtel D., Creationism controversy evolves, 28.11.2007, $<$ http://www.swissinfo.ch/eng/Home/Archive/Creationism_controversy_evolves.html?cid=6283640>, 15.02.2012.

2. Вертьянов С.Ю., Общая биология, Свято-Троицкаа Лавра, Москва 2005.

3. Clément P., Quessada M.P., Laurent C., Carvalho G., Science and Religion: Evolutionism and Creationism in Education. A survey of teachers conceptions in 14 countries, 2008, $<$ http://repositorium.sdum.uminho.pt/bitstream/1822 /8934/1/IOSTE_Evolution.pdf>, 13.02.2012.

4. Clouser R., „Is Theism Compatible with Evolution?”, [w:] R. T. Pennock [red.], Intelligent Design Creationism and its Critics: Philosophical, Theological, and Scientific Perspectives, MIT Press, Cambridge (MA)-London 2001.

5. Darwin Survey Shows International Consensus on Acceptance of Evolution, 30.06.2009, $<$ http://www.britishcouncil.org/darwin_now_survey_global.pdf $>$, 12.02.2012.

6. Doughty J., Doughty S., Creationism in Russia, <http://www.icr.org/article/creationism-russia>, 16.02.2012. 
7. Edis T., "Cloning Creationism in Turkey", Reports of the National Center for Science Education, 6 (1999), t.19, <http://ncse.com/rncse/19/6/cloning-creationismturkey $>$, 13.02.2012.

8. German

Scientists

Concerned

About Rise in Creationist Belief, 02.11.2006, <http://www.dw.de/dw/article/0,,2222454,00.html>, 15.02.2012.

9. Gross M., „US-style Creationism Spreads to Europe”, Current Biology, 8, t.12(2002).

10. Guessoum N., Islam's Quantum Question. Reconciling Muslim Tradition and Modern Science, I.B. Tauris, LondonNew York 2011

11. <http://tr.wikipedia.org/wiki/Harun_Yahya>, 14.02.2012.

12. Hyon C., The Creation Science Movement in Korea, $<$ ¡http://www.icr.org/article/creation-science-movementkorea/>, 16.02.2012.

13. Ipsos Global @dvisory: Supreme Beings, the Afterlife and Evolution, 25.04.2011, <http://www.ipsos-na.com/newspolls/pressrelease.aspx?id=5217>, 13.02.2012.

14. Johnson P., Darwin on Trial, InterVarsity Press, Downers Grove 1991.

15. Joyce J., Who are the British Creationists?, 15.09.2008, <http://news.bbc.co.uk/2/hi/7613403.stm>, 14.02.2012.

16. Junker R., Scherer S., Evolution: ein kritisches Lehrbuch, Weyel, Gießen 2006.

17. Kutschera U., Darwinism and Intelligent Design: The New Anti-Evolutionism Spreads in Europe, „Reports of the National Center for Science Education", 5-6, t.23 (2003). 
$<$ http://ncse.com/rncse/23/5-6/darwinism-intelligentdesign-new-anti-evolutionism-spreads-e $>$, 15.02.2012.

18. Kutschera U., „The German Anti-Darwin Industry”, Reports of the National Center for Science Education, 1, t.28 (2008), <http://ncse.com/rncse/28/1/german-anti-darwinindustry $>$, 15.02.2012.

19. Lackowski J., Decentralizacja zarzadzania polskim systemem oświatowym a społeczne nierówności edukacyjne, Wydawnictwo Uniwersytetu Jagiellońskiego, Kraków 2008.

20. Levit I., Hoßfeld U., Olsson L., „Creationism in the Russian Educational Landscape", Reports of the $\mathrm{Na}$ tional Center for Science Education, 5-6, , t.27 (2007). $<$ http://ncse.com/rncse/27/5-6/creationism-russianeducational-landscape $>$, 16.02.2012.

21. Lubaddeh J., „Contesting Evolution: European Creationists Take on Darwin", Spiegel Online, 25.02.2009, <ttp://www.spiegel.de/international/zeitgeist /0,1518,609712,00.html>, 15.02.2012.

22. Morris H.M., Clark M.E., The Bible Has the Answer, Master Books, Green Forest 1976.

23. Morris H.M., The Biblical Basis for Modern Science, Master Books, Green Forest 1984.

24. Nasr S.H., „Islam and Science”, [w:] P. Clayton, Z. Simpson (red.), The Oxford Handbook of Religion and Science, Oxford University Press, Oxford-New York 2009, s. 71-86.

25. Numbers R. (red.), Galileo Goes To Jail and Other Myths About Science and Religion, Harvard University Press, Cambridge (MA)-London 2009. 
26. Numbers R., The Creationists: From Scientific Creationism to Intelligent Design, Harvard University Press, Cambridge (MA) 2006.

27. Pennock R.T., „Why Creationism Should Not Be Taught in the Public Schools?", [w:] R. T. Pennock (red.), Intelligent Design Creationism and its Critics: Philosophical, Theological, and Scientific Perspectives, MIT Press, Cambridge (MA)-London 2001.

28. Retief L.W., „Calvin Meets the Hominins: A Brief History of Creationism in South Africa", Reports of the National Center for Science Education, 4, t.28 (2008). $<$ http://ncse.com/rncse/28/4/calvin-meets-homininsbrief-history-creationism-south-africa $>$, 17.02.2012.

29. Sayin Ü., Kence A., „Islamic Scientific Creationism”, Reports of the National Center for Science Education, 6, t.19 (1999), <http://ncse.com/rncse/19/6/islamic-scientificcreationism $>$, 14.02.2012.

30. Serbia Reverses Darwin Suspension, 09.09.2004, <http://news.bbc.co.uk/2/hi/europe/3642460.stm>, 16.02.2012.

31. Shipman P., „Turkish Creationist Movement Tours American College Campuses", Reports of the National Center for Science Education, 5, t. 26 (2006). $<$ http://ncse.com/rncse/26/5/turkish-creationistmovement-tours-american-college-campuses $>$, 14.02.2012.

32. Stephens

T., Swiss drag knuckles accepting evolution, 09.10.2006, <http://www.swissinfo.ch/eng/Home/Archive/Swiss_drag_knuckles_accepting_evolution.html?cid=70292>, 15.02.2012. 
33. Thompson B., The Scientific Case for Creation, Apologetics Press, Montgomery 1986.

34. Van Till H.J., „The Creation: Intelligently Designed or Optimally Equipped?", [w:] R. T. Pennock (red.), Intelligent Design Creationism and its Critics: Philosophical, Theological, and Scientific Perspectives, MIT Press, Cambridge (MA)-London 2001.

35. Wroe D., Intelligent design an option: Nelson, 11.08.2005, <http://www.theage.com.au/articles/2005/08/10 /1123353386917.html>, 17.02.2012

36. Wynne-Jones J., „Poll Reveals Public Doubts over Charles Darwin's Theory of Evolution", The Telegraph, 31.01.2009, <http://www.telegraph.co.uk/news/religion/4410927/Pollreveals-public-doubts-over-Charles-Darwins-theory-ofevolution.html>, 14.02.2012.

37. Yue V., "A Creationism Row in Hong Kong”, Reports of the National Center for Science Education, 6, t. 29 (2009), <http://ncse.com/rncse/29/6/creationism-rowhong-kong $>$, 17.02.2012.

\section{Abstract}

\section{Creationism and Intelligent Design outside the Uni- ted States - Outline of the Situation}

Contrary to stereotypical opinions which associate creationism and Intelligent Design (ID) movement only with American protestants, the phenomena cross national and denominational boundaries. After the USA, the second most important centre of creationism is the Muslim world. The example of Turkish creationist environment is given. The presence of creationism/ID in western Europe is interpreted as an effect of presenting the false 
alternative between science and religion to the public and poor training in data analysis among citizens. The specific character of Russian and South African creationism is considered. The missionary activity of creationist organisations, especially in South Korea, Hong Kong and Pacific region is described. Moreover, some problems connected with polling creationism are pointed out, a number of educational and legal issues is specified and psychological/social elements of supporting creationism/ID are mentioned.

Keywords: creationism, evolution, polls, intelligent design, Islam, education, Russia, Turkey, South Africa 